http://journal.nafo.int

J. Northw. Atl. Fish. Sci., Vol. 6: 95-100

\title{
Growth of Silver Eels (Anguilla rostrata) in Two Areas of Newfoundland*
}

\author{
Daniel R. Bouillon \\ Institute of Oceanography, McGill University \\ Montreal, Quebec, Canada H3A 2B2 \\ and \\ Richard L. Haedrich \\ Newfoundland Institute of Cold Ocean Science, Memorial University \\ St. John's, Newfoundland, Canada AIB 3X7
}

\begin{abstract}
Seaward-migrating American (silver) eels were collected with fyke nets in Dog Bay and Holyrood Bay on the northeast and south coasts of Newfoundland. In both areas, silver eels evidently undertake their spawning migration at ages 9 to 18 years (mean $12.9 \mathrm{yr}$ ), but the mean length and weight of eels from Dog Bay were significantly larger than those from Holyrood Bay. The smallest silver eel in the samples was $56.9 \mathrm{~cm}$ long, and all specimens were considered to be females because there are no records of males longer than 40 $\mathrm{cm}$ from Newfoundland waters. Growth of silver eels from the two areas was compared with the growth of silver and yellow (immature) eels from the Topsail area (near St. John's) in an earlier study. The size of the watersheds, inhabited by the eels prior to migration, may partly be reflected in the size of eels at the time of migration, because growth of eels was evidently faster in the area with the largest watershed than in the areas with smaller watersheds, probably reflecting variation in competition for food and space. Orbit diameter of silver eels from Newfoundland was larger than those of non-silver eels of the same size range from Lake Ontario, indicating that size of the eyes increases with onset of maturity.
\end{abstract}

\section{Introduction}

The American eel (Anguilla rostrata Leseuer) is a catadromous fish of considerable commercial importance that migrates from freshwaters of eastern North America, including Newfoundland, to spawn in the Sargasso Sea. It is believed that adult eels die after spawning and that the movement of larvae (leptocephali) and elvers back to the east coast of North America is predominantly passive in the ocean currents (Eales, 1968). American leptocephali and elvers may spend one or two years in the sea before entering freshwater streams and rivers (Smith and Saunders, 1955; Vladykov, 1970; Liew, 1974). Eels which have completed their growth and are leaving freshwater for the ocean are called "silver" eels. They presumably will reach sexual maturity by the time they get to their spawning grounds in the Sargasso Sea region. Gray and Andrews (1970) have shown that the state of maturity of silver eels (determined from ova diameters) leaving Topsail Pond in southeastern Newfoundland agree closely with data reported by Svardson (1949) for migrating silver eels ( $A$. anguilla) in Europe. Wenner (1973) stated that silver eels from Chesapeake Bay were more sexually advanced and migrate later in the season than eels of more northerly regions (Newfoundland). He suggested that this may act as a mechanism to allow fish from different regions to reach the spawning grounds at approximately the same time and reproductive condition.
In recent years, there has been growing interest among Newfoundland fishermen in catching eels. This has been in part due to promotion of this underutilized species by the Newfoundland Department of Fisheries. Effort is being concentrated on the autumn fyke-net fishery for silver eels, but there is also a pot-trap fishery for yellow (immature) eels throughout the summer. Increased fishing effort in certain localities has resulted in overfishing. Such areas are referred to as being "fished down". However, the nature of the life cycle of American eels indicates that no area is likely to remain fished down if fishing effort is relaxed (Eales, 1968).

Much literature exists on the age and growth of American and European eels (Frost, 1945a, 1945b; Smith and Saunders, 1955; Gunning and Shoop, 1962; Sinha and Jones, 1967; Gray and Andrews, 1971; Hurley, 1972; Facey and LaBar, 1981). Examination of otoliths (sagittae) is probably the most universallyaccepted method of age determination for eels, and otoliths are considered to provide more reliable indication of age than scales (Sinha and Jones, 1967). Bertin (1956) suggested that scales should not be used to age eels. The time of appearance of scales on the American eel seems to vary with geographic locality and growth (Smith and Saunders, 1955), and scales from the same area of the body may show different numbers of annual rings (Frost, 1945a; Vladykov, 1970). According to Frost (1945a), length (not age) determines the time of

\footnotetext{
* Contribution No. 63 from the Newfoundland Institute for Cold Ocean Science, Memorial University, St. John's, Newfoundland, Canada.
} 
appearance of scales on European eels. Liew (1974) compared ages from otoliths with known ages of American eels and concluded that otoliths can be used with confidence for age determination. Facey and LaBar (1981) stated that the use of otoliths to determine age is open to some speculation because of differences among researchers in interpreting annual rings and false annuli. Nevertheless, otoliths remain as the best available hard structure of the body for estimation of age (Deelder, 1976).

No studies have been undertaken to compare ages and sizes of silver eels in different regions of Newfoundland. Gray and Andrews (1971) examined the age and size of silver eels from Topsail Pond, near St. John's, and compared these with yellow eels from four other regions of Newfoundland. Vladykov (1966) examined adult eels from four rivers of southern Newfoundland, but he was only interested in the sex ratio for comparison with samples from other areas of North America. The objective of the present study was to compare the growth, in terms of size and age at time of migration, of silver eels from the north and south coasts of Newfoundland and to compare these results and orbital eye diameter with existing data for other regions.

\section{Materials and Methods}

American eels were caught in fyke nets in Dog Bay, Notre Dame Bay, on the northeast coast of Newfoundland and in Holyrood Bay, St. Mary's Bay, on the south coast (Fig. 1). The fyke nets, with mesh size (stretched) of $25 \mathrm{~mm}$, were placed at the mouths of

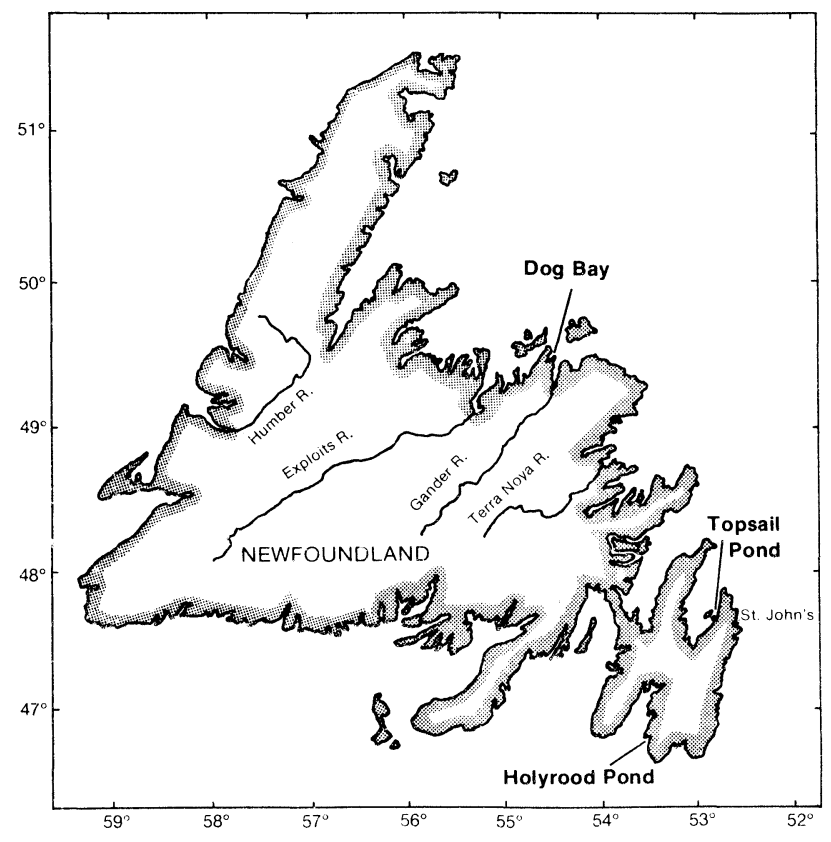

Fig. 1. Locations of silver eel sampling sites in Newfoundland. rivers to trap eels that were moving downstream toward the sea. The gear was non-selective and trapped all eels and other fish as they moved downstream. Sampling was carried out within one week of fishing in each area, with 94 silver eels being taken in Dog Bay and 90 in Holyrood Bay. The collections were made in late September and early October (1981) when the largest downstream migration usually occurs. The eels were stored in frozen condition until they were examined about a month after capture.

In addition to the migrating silver eels, immature yellow eels were also captured. The silver eels varied somewhat in coloration but typically they had dark backs and very prominent, silver or milky white bellies. Yellow eels were usually smaller, and, in the majority of cases, had very distinct yellow coloration on their bellies. Variations between these extremes also occurred. Silver eels possessed a distinct bronze or more usually silver band of variable width along their sides and occasionally had blotched or dull-colored bellies. These eels showed no sign of yellow coloration anywhere on their bodies. Borderline specimens which could not be identified with assurance as yellow or silver eels were not used in this analysis.

After thawing in the laboratory, the total length of each eel was measured to the nearest millimeter from the tip of the lower jaw to the end of the longest caudal fin ray and the weight was recorded to the nearest gram. Horizontal eye diameter was determined to the nearest $0.05 \mathrm{~mm}$ with Vernier calipers. Eel gonads were not examined histologically in the present study and thus sex was not determined directly.

A dorsal transverse incision midway between the posterior edge of the eyes and the first gill opening exposed the otoliths, which were removed with forceps, wiped clean and stored dry until they were used for age determination. Subsequently, each pair of otoliths was mounted on standard microscope slides with Buehler epoxide (resin and hardener) and heated to speed up the hardening process. The otoliths were ground close to the nucleus center with a Hillquist grinder which had a diamond-impregnated brass cup wheel. In most cases, the surfaces were polished with fine carborundum powder, but annual rings occasionally showed up clearly before the surfaces were polished.

The otoliths were immersed in methyl-benzoate to improve resolution and examined by transmitted light under a binocular microscope (100X). Opaque zones were interpreted as being formed during the summer and hyaline zones during the winter (Gray and Andrews, 1971; Liew, 1974). False annuli (checks and supplementary zones) were identified as those narrow zones which did not form a complete ring when adja- 
cent primary zones did or as weak rings whose position did not correspond to the general concentric pattern of the otolith. The central nucleus of the otolith, which represents the time spent in the ocean as leptocephalus larva and glass eel, was not counted. Therefore, the age of eels in this study refers only to the length of time spent in freshwater. Because the eels were collected in early autumn, each otolith exhibited an opaque zone around its perimeter. Following the procedure of Gray and Andrews (1971), this zone was not considered when determining the age.

\section{Results}

The mean length and mean weight of 94 migrating American eels (termed silver eels) from Dog Bay were both significantly higher $(P<0.01)$ than the corresponding values for 90 silver eels from Holyrood Bay (Table 1). In both areas, some eels began their migration as early as age 9 (freshwater age) and some did not undertake migration until age $18 \mathrm{yr}$. The mean age at migration was essentially the same in both areas: 13.0 yr $(S D=1.48)$ in Dog Bay and $12.9 \mathrm{yr}(S D=1.64)$ in Holyrood Bay. The smallest migrating eel was $56.9 \mathrm{~cm}$ $(387 \mathrm{~g})$ and $11 \mathrm{yr}$ old. Because males are known to be significantly smaller than females of the same age (see Discussion), all of the silver eels in this study were considered to be females.

Comparable data for silver and yellow eels from Topsail, Newfoundland (Gray and Andrews, 1971), are also given in Table 1. Silver eels from Dog Bay were larger than those from Holyrood Bay at almost all ages, and these fish from the present study tended to have greater mean length and mean weight than the silver eels from Topsail Pond for all ages less than $16 \mathrm{yr}$. The samples from all three areas exhibited great variation in length and weight at each age.

The length and age compositions of the samples from Dog Bay and Holyrood Bay appear to be normally distributed (Fig. 2). The age compositions for both areas were essentially the same with modes at $13 \mathrm{yr}$. The length compositions exhibited a $5-\mathrm{cm}$ difference in the modes, with eels from Dog Bay evidently undertaking their downstream migration at a greater length and weight than the eels in Holyrood Bay. The exponential regressions of weight on length for both areas were highly correlated $(r>0.93)$ and indicate that eels from Dog Bay were, on the average, heavier than those of the same lengths from Holyrood Bay (Fig. 3).

Mean length-at-age data for silver eels from the present study and earlier silver eel data from Topsail Pond, near St. John's (Gray and Andrews, 1971) illustrate the variation in growth among areas (Fig. 4). The mean length-at-age data for immature yellow eels from the Topsail Pond area (Gray and Andrews, 1971) are
TABLE 1. Length and weight data by age for silver eels from Dog Bay and Holyrood Bay in the present study, and similar data (Gray and Andrews, 1971) for silver and yellow eels from Topsail, Newfoundland. (SD = standard deviation.)

\begin{tabular}{|c|c|c|c|c|c|c|c|}
\hline \multirow{2}{*}{$\begin{array}{l}\text { Age } \\
(y r)\end{array}$} & \multirow{2}{*}{$\begin{array}{c}\text { No. of } \\
\text { fish }\end{array}$} & \multicolumn{3}{|c|}{ Length $(\mathrm{cm})$} & \multicolumn{3}{|c|}{ Weight (g) } \\
\hline & & Range & Mean & SD & Range & Mean & $\overline{S D}$ \\
\hline \multicolumn{8}{|c|}{ Dog Bay (silver eels) } \\
\hline 9 & 1 & - & 71.9 & - & - & 662 & - \\
\hline 10 & 3 & $66-80$ & 74.4 & 7.4 & $557-1,008$ & 819 & 234 \\
\hline 11 & 11 & $71-86$ & 77.3 & 5.5 & $700-1,293$ & 945 & 201 \\
\hline 12 & 21 & $64-91$ & 75.4 & 6.5 & $540-1,388$ & 875 & 231 \\
\hline 13 & 27 & $68-90$ & 76.0 & 6.4 & $575-1,463$ & 878 & 211 \\
\hline 14 & 16 & $69-93$ & 80.4 & 5.5 & $662-1,440$ & 1,107 & 194 \\
\hline 15 & 12 & $77-89$ & 82.3 & 4.1 & $944-1,542$ & 1,165 & 196 \\
\hline 16 & - & - & - & - & - & - & - \\
\hline 17 & 2 & $84-91$ & 87.4 & 5.2 & $1,263-1,650$ & 1,457 & 273 \\
\hline 18 & 1 & - & 87.4 & - & - & 1,338 & - \\
\hline 13.0 & 94 & $64-93$ & 77.8 & 6.5 & $540-1,650$ & 971 & 250 \\
\hline \multicolumn{8}{|c|}{ Holyrood Bay (silver eels) } \\
\hline 9 & 2 & $67-76$ & 71.3 & 6.4 & $618-666$ & 642 & 34 \\
\hline 10 & 3 & $61-66$ & 64.4 & 2.7 & $554-564$ & 556 & 11 \\
\hline 11 & 11 & $57-77$ & 66.1 & 4.7 & $387-836$ & 545 & 117 \\
\hline 12 & 21 & $60-76$ & 70.8 & 4.3 & $443-956$ & 665 & 133 \\
\hline 13 & 22 & $61-79$ & 71.4 & 4.9 & $428-917$ & 697 & 141 \\
\hline 14 & 20 & $65-82$ & 73.3 & 5.0 & $527-980$ & 792 & 134 \\
\hline 15 & 5 & 78-91 & 83.3 & 5.1 & $788-1,347$ & 1,088 & 239 \\
\hline 16 & 3 & $65-77$ & 71.4 & 5.7 & 512-901 & 731 & 199 \\
\hline 17 & 3 & $83-89$ & 86.6 & 3.6 & $1,225-1,396$ & 1,338 & 98 \\
\hline 12.9 & 90 & $57-91$ & 72.2 & 6.5 & $387-1,396$ & 730 & 212 \\
\hline
\end{tabular}

Topsail Pond (silver eels)

\begin{tabular}{|c|c|c|c|c|c|}
\hline 9 & 5 & $54-62$ & 58.7 & $224-377$ & 318 \\
\hline 10 & 5 & $60-65$ & 61.7 & $256-448$ & 393 \\
\hline 11 & 13 & $58-68$ & 64.5 & $312-563$ & 467 \\
\hline 12 & 34 & $58-71$ & 67.6 & $257-665$ & 531 \\
\hline 13 & 20 & $68-76$ & 71.9 & $462-828$ & 608 \\
\hline 14 & 6 & $71-80$ & 74.3 & $656-1,132$ & 752 \\
\hline 15 & 6 & $79-86$ & 81.5 & $708-1,277$ & 1,014 \\
\hline 16 & 1 & - & 86.8 & - & 1,103 \\
\hline 17 & 1 & - & 92.4 & - & 1,517 \\
\hline 18 & 1 & - & 93.1 & - & 1,413 \\
\hline 12.3 & 92 & $54-93$ & 69.4 & $224-1,517$ & 592 \\
\hline \multicolumn{6}{|c|}{ Topsail Barachois (yellow eels) } \\
\hline 4 & 2 & $24-26$ & 24.9 & $19-20$ & 20 \\
\hline 5 & 5 & $26-30$ & 27.7 & $24-34$ & 30 \\
\hline 6 & 19 & $29-41$ & 34.3 & $36-91$ & 59 \\
\hline 7 & 20 & $36-48$ & 41.8 & $69-178$ & 120 \\
\hline 8 & 27 & $44-58$ & 49.3 & $113-480$ & 211 \\
\hline 9 & 45 & $50-63$ & 55.3 & $197-551$ & 318 \\
\hline 10 & 12 & $61-74$ & 65.2 & $415-726$ & 530 \\
\hline 11 & 4 & $66-76$ & 70.6 & $682-1,040$ & 786 \\
\hline \multirow[t]{2}{*}{12} & 1 & - & 74.8 & - & 853 \\
\hline & 135 & $24-76$ & & $19-1,040$ & \\
\hline
\end{tabular}

also given to illustrate their growth in relation to that of silver eels in freshwater. Generally, except for the older age-groups $(>16 \mathrm{yr}$ ), silver eels from Dog Bay exhibited the greatest mean lengths-at-age, followed by those from Holyrood Bay and then Topsail Pond. The differences in growth may be related to the sizes of the watersheds in the different areas. The Dog Bay 


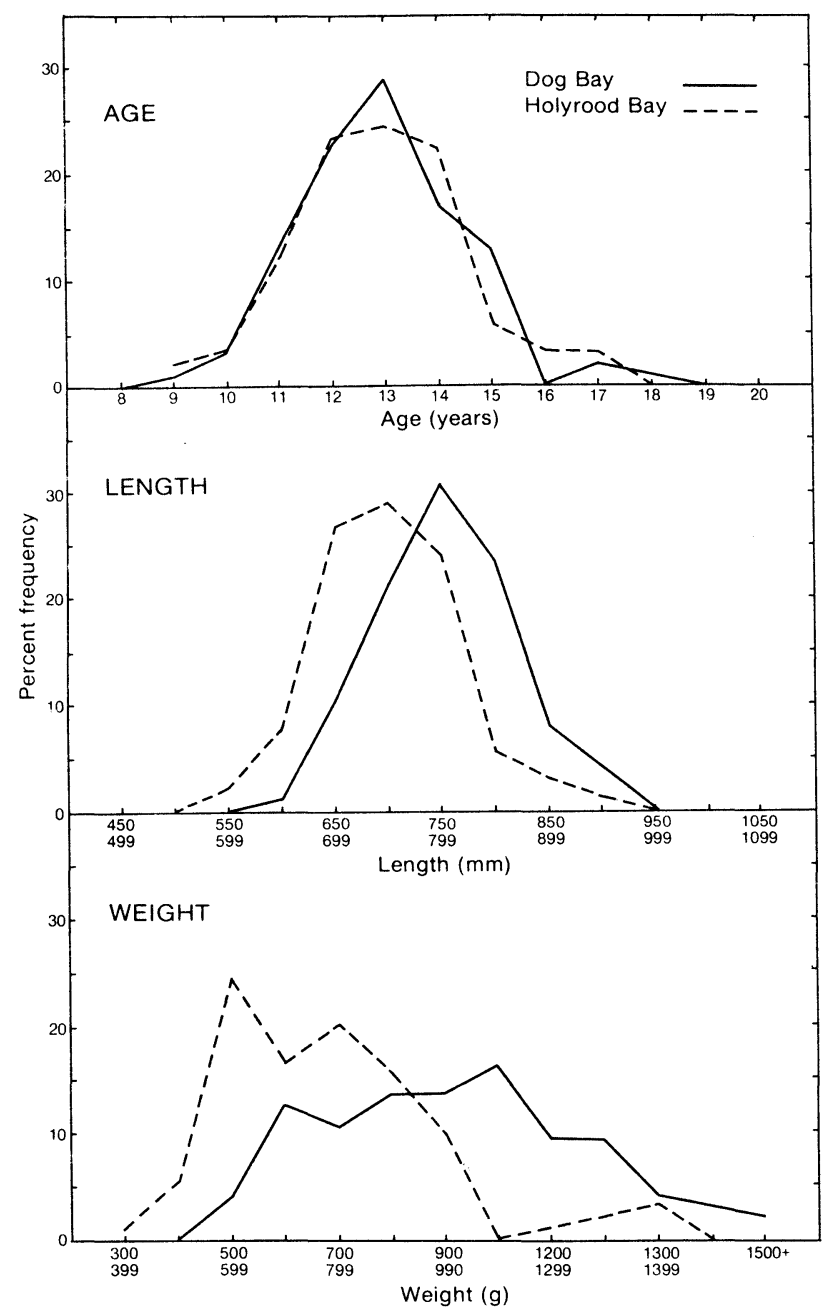

Fig. 2. Age, length and weight compositions of silver eels in samples from Dog Bay and Holyrood Bay, Newfoundland.

watershed $\left(440 \mathrm{~km}^{2}, 23\right.$ lakes $)$ is larger than the Holyrood Bay watershed $\left(320 \mathrm{~km}^{2}, 17\right.$ lakes), and both are much larger than the Topsail Pond watershed $\left(13 \mathrm{~km}^{2}\right.$, 2 lakes). The relatively small differences between the mean lengths-at-age of silver eels from Holyrood Bay and Topsail Pond do not correspond to the difference in sizes of their watersheds.

Comparison of the relationship between horizontal eye diameter and fish length in migrating silver eels from Dog Bay and Holyrood Bay (samples combined) with non-migrating eels of similar size from Lake Ontario (Hurley, 1972) indicates that the former have considerably larger eyes than the latter (Fig. 5).

\section{Discussion}

The range of silver eel ages in this study $(9-18 \mathrm{yr})$ was the same as that for silver eels migrating from Topsail Pond, Newfoundland (Gray and Andrews, 1971), and was similar to that reported by Frost (1945b)

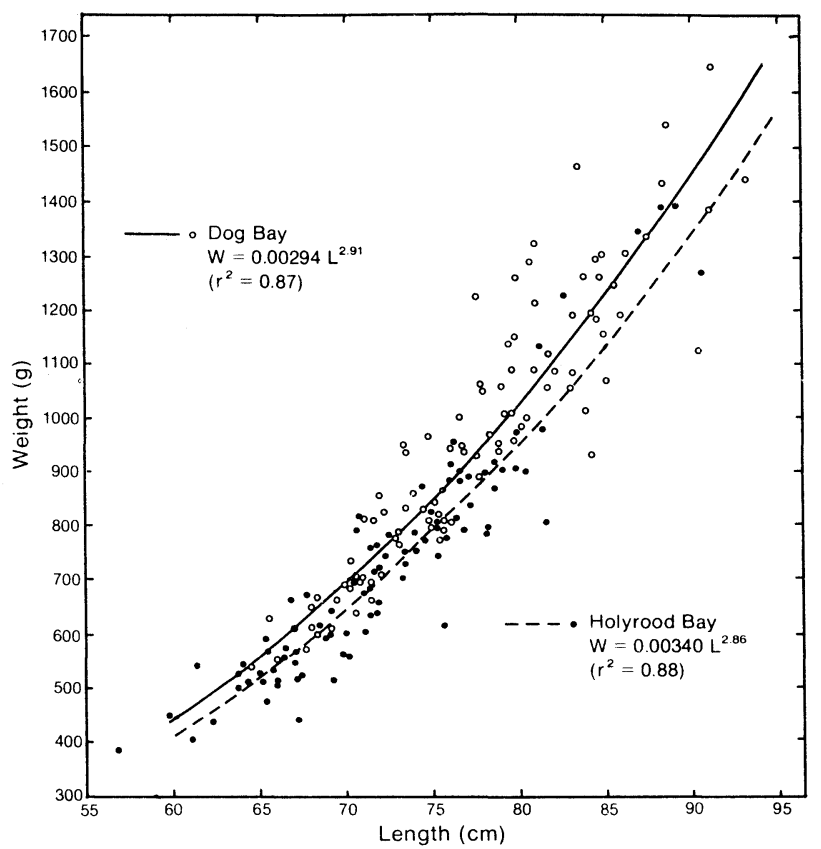

Fig. 3. Length-weight relationships for silver eels from Dog Bay and Holyrood Bay, Newfoundland.

for European eels in Lake Windermere, England. The corresponding mean ages in the three studies were $12.9,12.3$ and $12.3 \mathrm{yr}$ respectively.

Vladykov (1966) noted that adult (female) eels in the Canadian Atlantic Provinces do not reach as large a size as those in the Canadian Great Lakes region, especially Ontario and Quebec. Newfoundland silver eels evidently attain the largest size at Dog Bay, followed by Holyrood Bay and Topsail Pond. The Dog Bay watershed is larger and contains more lakes than that of Holyrood Bay, and both systems are larger than the Topsail Pond watershed. Differences in growth of eels among the three systems may be due, in part, to differences in the extent of intraspecific competition, because elvers which enter the larger systems have a greater opportunity to spread out and reduce their density. This assumes that the numbers of elvers which enter the larger systems each year do not exceed the carrying capacity of the systems, and it does not take into account such factors as interspecific competition and the commercial fisheries. There has been a sustained fishery for yellow eels in Dog Bay for several years, but the eel fishery in Holyrood Bay has been sporadic. Eel fishing does not take place on a commercial scale in the Topsail Pond area.

Frost (1945b) suggested that size rather than age is the factor which induces migration in European eels. In the present study, the mean lengths of migrating silver eels at different sites in Newfoundland varied considerably, but the mean ages at these sites and at Windermere (Frost, 1945b) were similar, indicating that age rather than length may be more important in 


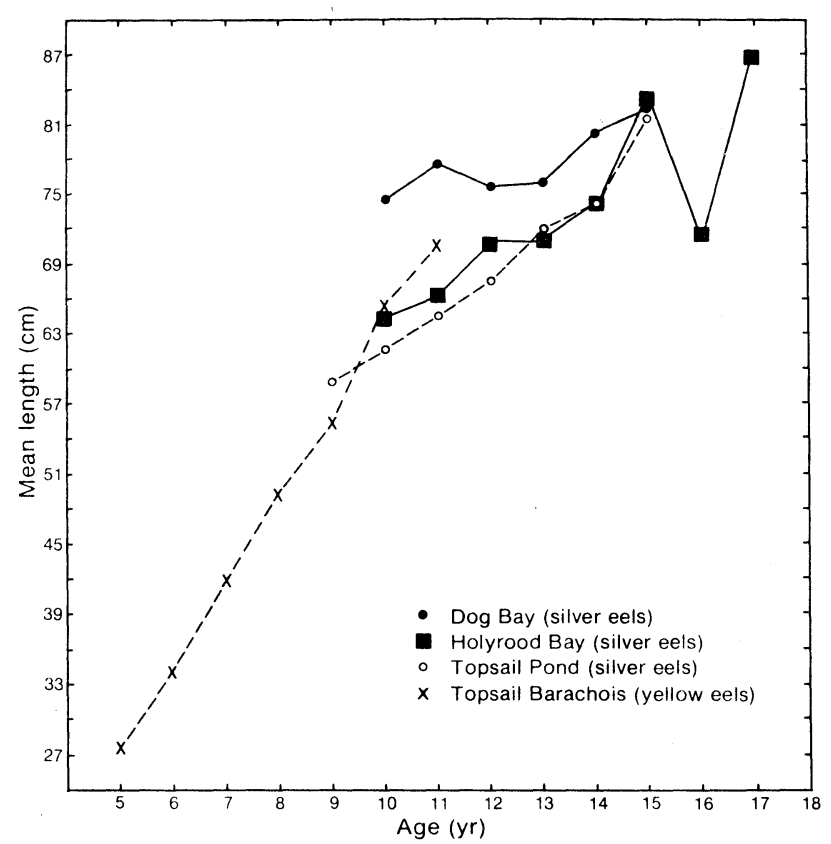

Fig. 4. Comparison of mean length-at-age data for silver eels from Dog Bay and Holyrood Bay with similar data for silver and yellow eels from Topsail Pond (Gray and Andrews, 1971).

inducing migration. However, it is likely that neither length nor age alone is responsible for inducing migration, because the mean age of eels in Lake Champlain (15.9 yr) (Facey and LaBar, 1981) is higher than those in the aforementioned studies. As Frost (1945b) suggested, measures of length (and age) of silver eels may only provide an index of some physiological condition that is associated with the onset of maturation and subsequent migration to the sea.

Sexual dimorphism in the American eel is not apparent and failure to examine gonadal tissue histologically can result in misidentification of sex (Gray and Andrews, 1970; Dolan and Power, 1977). Male American eels are significantly smaller than female silver eels of the same age and are rarely observed at northern latitudes (Vladykov, 1966, 1970; Gray and Andrews, 1970; Hurley, 1972; Wenner and Musick, 1974; Winn et al., 1975; Dolan and Power, 1977; Facey and LaBar, 1981). Rossi and Columbo (1979) have reported that, when male European eels are sufficiently represented in a sample, the length distribution is bimodal. This is not the case in the present study, and it is unlikely that males, if present in the streams, were missed as a result of the sampling techniques. Furthermore, Dolan and Power (1977) state that a review of the literature revealed no evidence to confirm the postulated "female-freshwater, male-saltwater" theory. The largest male American eel that has been recorded was a $50.3 \mathrm{~cm}$ specimen taken in Quebec (Dolan and Power, 1977). The largest male eel from Newfoundland was $34.9 \mathrm{~cm}$ (Vladykov, 1970). Of 354 eels (including 92 silver eels) from Newfoundland that were examined by Gray and Andrews (1971), only one

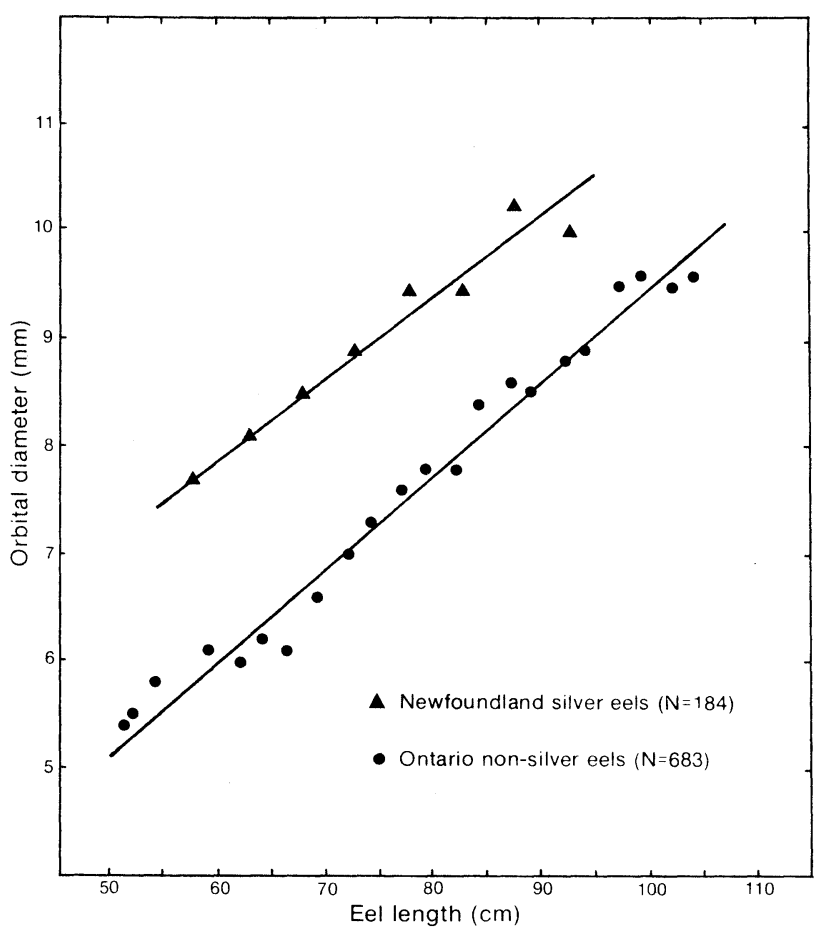

Fig. 5. Relationship between horizontal eye diameter and fish length for migrating silver eels from Newfoundland, in relation to that for non-silver eels from Lake Ontario (Hurley, 1972).

yellow eel $(25.2 \mathrm{~cm})$ was a male. Because the smallest eel in the present study was $56.9 \mathrm{~cm}$, it can be stated with reasonable confidence that all eels from the two locations in Newfoundland were female.

Growth varied considerably among individual eels in the same locality, as evidenced by the great variation in length-at-age, and among populations in the different localities (Dog Bay, Holyrood Bay, Topsail Pond). Large variations in growth have been observed elsewhere for American eels (Smith and Saunders, 1955; Gunning and Shoop, 1962, Gray and Andrews, 1971; Hurley, 1972; Facey and LaBar, 1981) and for European eels (Frost, 1945b; Bertin, 1956; Sinha and Jones, 1967). Hurley (1972) suggested that some of the variation in length-at-age may be due to difficulties in reading otoliths.

According to Vladykov (1970), the diameter of the eyes in American eels enlarges considerably during the process of maturation. Migrating adult European eels are also known to have enlarged eyes (Winnet al., 1975). Hurley (1972) found no evidence of enlarged eyes in the largest eels which he collected from Lake Ontario, but the eels in his samples were neither classified as silver eels nor migrating to sea at the time of capture. Data from the present study show that migrating silver eels from Newfoundland have larger eyes than non-silver eels of similar lengths from Lake Ontario. This observation supports the hypothesis that eye enlargement is indicative of the onset of sexual maturation. 


\section{Acknowledgements}

We thank Adolf Mann, Olindo Hodder and Joe Abraham for their special efforts to accommodate our requests for eel samples. The College of Fisheries, St. John's, Newfoundland, provided freezing and storage facilities, and the Department of Geology, Memorial University, provided the use of lapidary facilities. We are grateful to the Newfoundland Department of Fisheries for financial support.

\section{References}

BERTIN, L. 1956. Eels: a biological study. Cleaver-Hume Press, London, $192 \mathrm{p}$.

DEELDER, C. L. 1976. The problem of the supernumary zones in otoliths of the European eel, Anguilla anguilla (Linnaeus, 1758); a suggestion to cope with it. Aquaculture, 9: 373-379.

DOLAN, J. A., and G. POWER. 1977. Sex ratio of American eels, Anguilla rostrata, from the Matamek River system, Quebec, with remarks on problems in sexual identification. J. Fish. Res. Board Can., 34: 294-299.

EALES, J. G. 1968. The eel fisheries of eastern Canada. Bull. Fish. Res. Board Can., 166, 79 p.

FACEY, D. E., and G. W. LABAR. 1981. Biology of American eels in Lake Champlain, Vermont. Trans. Amer. Fish Soc., 110: 396-402.

FROST, W. E. 1945a. The age and growth of eels (Anguilla anguilla) from the Windermere catchment area, Part I. J. Anim. Ecol., 14(1): 26-36.

1945b. The age and growth of eels (Anguilla anguilla) from the Windermere catchment area, Part 2. J. Anim. Ecol., 14(2): 106-124.

GRAY, R. W., and C. W. ANDREWS. 1970. Sex ratio of the American eel (Anguilla rostrata LeSueur) in Newfoundland waters. Can. J. Zool., 48: 483-487.
1971. Age and growth of the American eel (Anguilla rostrata LeSueur) in Newfoundland waters. Can. J. Zool., 49: 121-128.

GUNNING, G. E., and C. R. SHOOP. 1962. Restricted movements of the American eel Anguilla rostrata LeSueur in freshwater streams with comments on growth rate. Tulane Stud. Zool., 9: 265-272.

HURLEY, D. A. 1972. The American eel (Anguilla rostrata) in eastern Lake Ontario. J. Fish. Res. Board Can., 29: 535-543.

LIEW, P. K. L. 1974. Age determination of American eels based on the structure of their otoliths. In Ageing of fish, T. B. Bagenal (ed.), Unwin. Bros. Ltd., Surrey, England, 234 p.

ROSSI, R., and G. COLOMBO. 1979. Some observations on age, sex, and growth of silver eels (Anguilla anguilla L.) in north Adriatic lagoons. ICES Rapp. Proc.-Verb., 174: 64-69.

SINHA, V. R. P., and J. W. JONES. 1967. On the age and growth of the freshwater eel (Anguilla anguilla). J. Zool., 153: 99-117.

SMITH, M. W., and J. W. SAUNDERS. 1955. The American eel in certain fresh waters of the Maritime Provinces of Canada. J. Fish. Res. Board Can., 12: 238-269.

SVARDSON, G. 1949. Eels (Anguilla anguilla) found in Sweden in partial nuptial dress. Rep. Inst. Freshw. Res., Drottning., 29: 129134.

VLADYKOV, V. D. 1966. Remarks on the American eel (Anguilla rostrata LeSueur): sizes of elvers entering streams, the relative abundance of adults and females, and the present importance of eels in North America. Verh. Int. Ver. Limnol., 16: 1007-1017.

1970. Progress reports Nos. 1 to 5 of the American eel (Anguilla rostrata) studies in Canada. Can. Dept. Fish. Forest. Progr. Rep. 1-5 Project, No. 32, 98 p.

WENNER, C. A. 1973. Occurrence of American eels, Anguilla rostrata, in waters overlying the eastern North American continental shelf J. Fish. Res. Board Can., 30: 1752-1755.

WENNER, C. A., and J. A. MUSICK. 1974. Fecundity and gonad observations of the American eel, Anguilla rostrata, migrating from Chesapeake Bay, Virginia. J. Fish. Res. Board Can., 31: 1387-1391.

WINN, H. E., W. A. RICHKUS, and L. K. WINN. 1975. Sexual dimorphism and natural movements of the American eel (Anguilla rostrata) in Rhode Island streams and estuaries. Helgoland. Wiss. Meeresunters., 27: 156-166. 